\title{
Lucian Blaga - the translation theorist
}

\author{
Carmen-Ecaterina Ciobâcă ${ }^{\circledR *}$ \\ Faculty of Law, "Alexandru Ioan Cuza" University, Bd. Carol I 11, 700506 Iaşi, Romania
}

\section{Article info}

History:

Received August 14, 2019

Accepted September 5, 2019

Published November 7, 2019

Key words:

translation

compared analysis

linguistic contact

\begin{abstract}
Our research focuses on the metatexts signed by Lucian Blaga as a translator. We prove that, due to the preference of Blaga for ethnocentric translation and his philosophy on poetic translation seen as interpretation, he is a translation theorist. The premise on which we base our research is represented by the remark belonging to Sean Cotter, according to which, in the case of Blaga, translation is a manner of challenging the linguistic policy imposed in Romania during the 1950 s by the new regime. In this regard, we analyse the dichotomy margins vs centre in translation and the importance of the translation process in Romania during that decade. The pattern suggested by Lawrence Venuti in nowadays Translation Studies is reversed in the case of the translation subjected to our study: the translator abandons its "invisibility", while ethnocentric translation becomes, in itself, a technique of resistance. The analysis of certain metatexts signed by Blaga proves that he had a modern philosophy on translation, which allows us to consider him a translation scholar avant la lettre. Thus, a careful analysis of metatexts signed by translators of that period would contribute to a greater visibility of trends existing in Romanian Translation Studies.
\end{abstract}

\section{Introduction. Lucian Blaga - translator and translation thinker}

Based on a recurrent and legitimate debate existing for a few years in Romania, namely the existence of a specific tradition in Romanian Translation Studies, this paper analyses an issue that was neglected by critics or has acquired a secondary place: the existence of a metadiscourse on translation belonging to translators themselves. This metadiscourse is to be found in prefaces, notes of translators, papers published in literary or linguistic journals. The example chosen here is represented by certain metatexts signed by Lucian Blaga as a translator, among which his paper entitled Faust si problema traducerilor [Faust and the Issue of Translations], published for the first time as Cum l-am tradus pe Faust [Translating Faust] in the journal "Steaua" in 1957 and, later, in the volume Isvoade: eseuri, conferințe și articole [Notes: Essays, Conferences and Papers], printed in Bucharest in 1972.

Taking into account the area and the historical context in which the translation of Faust is published (1955, the Popular Republic of Romania, when the Stalinist ideology was imposed, including as a linguistic policy), the position of the Romanian poet and philosopher Lucian Blaga (considered "mystical" and, therefore, prohibited as an author in the new communist era, working only as a "humble" translator) and the success of the translation of Faust, which was very popular probably due to the reputation of the translator, the translation subject to our study is, without doubt, one to last: in the case of Blaga, translation becomes a subtle symbol of resistance to the oppressive communist regime. It is perhaps also for this reason that the translator wanted to present to the general public some reflections on the translation of the work of Goethe: the translation methodology, the translation difficulties, the solutions envisaged. The attentive reader will also find in this confession of the translator some reflections that do not refer only to the translation labour, but also prove a high ideological level, surprising for that era (the late 1950s, when Translation Studies did not exist as a field and translation debates were part of

\footnotetext{
`Email address: carmen.ciobaca@gmail.com.
} 
linguistics). Therefore, we find in the confession of Blaga an ideology concerning the translation process that is close to the thinking of some Translation Studies scholars from the French milieu, such as Antoine Berman and Henri Meschonnic, and from the German milieu, familiar to the translator, such as Friedrich Schleiermacher. This proves that, over time, we may find a movement of ideas and a strong community of translation theorists.

As we have emphasized, our analysis takes into account at all times the historical, ideological and social context in which the translator works and, later on, expresses his ideology on translation. The confession of Blaga is not accidental; as Sean Cotter ${ }^{1}$ states in his work entitled Literary Translation and the Idea of a Minor Romania, this confession is the expression of a rebellion, of a technique of resistance:

Blaga spent the first decade of the Communist rule revising his earlier cultural philosophy and becoming the nation's celebrity literary translator. Blaga's focus on translation resulted in the most complete and compelling imagination of Romania as a minor nation, and his best-selling translations made him, despite (and because of) his alienation of the Communist regime, a national translator. ${ }^{2}$

(Cotter, 2014, p. 5)

Therefore, ironically, Blaga becomes, during the later part of his life, "the national translator", which contradicts the "invisibility" paradigm formulated later on in Translation Studies by Lawrence Venuti. Prohibited as an author, Blaga becomes visible as a translator and makes known the frustration of an oppressed nation through his translation methodology and ideology.

In the following section, we examine the historical and social context in which the translation of Faust is published and in which the translator reveals his ideology. In this respect, we emphasize the features of the "golden age of Romanian translation", as Sean Cotter describes the first decade of soviet occupation (Cotter, 2014, p. 28) ${ }^{3}$. An important role in this debate is played by the centre vs margins dichotomy in translation (the general trend is to translate from central languages and literatures into minor, peripheral languages, such as Romanian), but also by the alienation/foreignization technique, also called exocentric translation, and the assimilation/domestication technique, also called ethnocentric translation (in French: traduction sourcière and traduction cibliste, respectively). Exocentric translation preserves the foreign and unknown character of the source text and culture, whereas ethnocentric translation aims to level foreign traits and to adapt them to the target culture ${ }^{4}$. Cotter (2014) states that the theory of Lawrence Venuti concerning the universal applicability of these two translation strategies is not valid in the case of "minor" languages and cultures. In this section we also present the reasons for which, in the case of Blaga, translation becomes an act of resistance to the oppressive Soviet regime.

The third section contains the analysis of the translation ideology of Lucian Blaga; we expose the reasons for which we consider that his reflexion on translation is close to ideas belonging to renowned translation scholars, such as Antoine Berman or Henri Meschonnic. Not coincidentally, the translation strategies suggested by Blaga are a manifestation of his rebellion against the alienation affecting the Romanian language in those years. Thus, Blaga becomes a translation theorist avant la lettre.

The conclusion of our paper gets back to the debate concerning the existence of a specific tradition in Romanian Translation Studies. We focus on the importance of metatexts produced by translators who become translation ideologues in nuce. Last but not least, we emphasize that the translator does not enjoy total freedom: he/she is constrained by the historical context and ideology of his/her era. Nevertheless, the historical context and ideology are not invincible if the translator makes use of appropriate strategies

\footnotetext{
${ }^{1}$ Professor of literature and literary translation at the University of Texas and translator of Romanian literature.

${ }^{2}$ In this paper, we use italics in order to emphasize phrases we consider relevant in quoted texts.

3 "As a result of this ideological connection as well as the quality and quantity of translations produced, we may call the early communist period, with moderate irony, a golden age of Romanian translation” (Cotter, 2014, p. 28).

${ }^{4}$ Non-ethnocentric translation is also called by Berman (1995, p. 4) "literal translation". In our paper, we use the phrase "exocentric translation" in order to designate this concept.
} 
and his/her translation approach is based on the understanding of the context and on an individual reflexion on translation.

\section{Centre vs margins in translation}

One of the dichotomies existing in Translation Studies is represented by the terms centre vs margins, mostly reflecting an uneven power ratio between central languages/cultures and "marginal" languages/cultures, which are less known and represented. This paradigm, which is not discriminatory on purpose, but the natural result of supply and demand on the translation market, has a significant impact on languages from which/into which one translates. Gisèle Sapiro states that the global translation flow is an asymmetrical one, the general movement going from the centre towards the margins; thus, certain languages have a central position (English, followed by German, French and Russian) and all other languages have a "marginal" position (Sapiro, 2012, p. 33). In other words, "marginal" languages and, by extension, "marginal" cultures have less speakers, have a less important impact at a global level and publish a smaller number of books by comparison with widely spoken languages. In the jargon of translators, marginal languages are also called "rare languages".

Thus, it is more likely for a "marginal nation" to translate from central languages than for its writings to be translated into such languages. There are, of course, specific exceptions: a translation from a marginal language may be in demand due to the reputation of the author, a specific exoticism of the source work or the existence of specific cultural policies established at the level of the marginal state. Incidentally, we may emphasize that the translation from a marginal language into another marginal language implies a paradox: as it is highly unlikely to find translators for these two languages, the source text is frequently another translation, carried out in a central language ${ }^{5}$. Therefore, marginal languages and literatures are less well represented and less well known as a result of this uneven ratio of supply and demand on the translation market, which is essentially generated by certain asymmetries of power.

In the book Literary Translation and the Idea of a Minor Romania, Sean Cotter examines the importance of the translation process in the creation of the image of Romania as a "minor nation", taking as an example the translations performed by three renowned Romanian authors: Lucian Blaga, Constantin Noica and Emil Cioran. The book establishes a link between translation as a practice and the marginal position a nation recognizes for itself'.

We underline that the terms "the minor" (noun) and "minor" (adjective) used by Sean Cotter do not involve a negative meaning. Already from the title, we discover the phrase "minor Romania" ("Romania as a marginal area"), a state whose language and literary culture are rather unknown to Western translation scholars, as Cercel (2017, p. 75) emphasizes. Also, the key concept of the book, "the minor" ("the marginal status"), has a different meaning than in the general discourse: the term "minor" does not involve here a lack of cultural significance or an inferiority complex, but an active manner of imagining a specific nation (Cercel, 2017, p. 75). The concept of "minor nation/language" is defined as "a nation/language that translates", without implications related to the importance/lack of importance of the said nation/language: "The minor is not a failed state or a potentially great one, but a translated nation. As the Romantic poem was to the nineteenth-century nation, the translation is to these writers' twentieth" (Cotter, 2014, p. 2). We have found the same idea in a paper signed by Jeanrenaud (2015), who states that "precisely the cultures developed by « minority » languages are translation cultures par excellence" (p. 2). Therefore, the Romanian culture, having a minor position, is in itself a culture of translation and translations produced

\footnotetext{
${ }^{5}$ As an example, the translation into Romanian of the novel Cel care mă așteaptă [The Book of Fate] by Parinoush Saniee, published by Polirom Publishing House, Iași, 2012, is carried out from Italian, a central language, even if the novel is originally written in Persian, a marginal language.

"The concepts "the minor" and "minor" used by Sean Cotter in his book correspond to the terms we have used above, namely "margins" and "marginal". In what follows, we resort to the terminology of Sean Cotter, which does not have negative implications, but only defines the position of a marginal nation/language.

6"This study is an attempt to describe the connections of translation and « minor-mindedness »" (Cotter, 2014, p. 7).
} 
in this context pertain to a minor area (Sean Cotter defines them as "minor translations"). The target language is decentred, which allows its contact with other languages which have a central position ${ }^{7}$.

Sean Cotter states that, if translations can be grouped into two categories (translations produced in central areas and in minor areas), existing translation theories should also be reconsidered. In particular, research on translation has constantly neglected translations produced in minor areas, which is wrong, because the power ratio in such areas is different ${ }^{8}$. If classical translation theories have focused, perhaps fastidiously, on the matter of faithfulness and the possibility of preserving in the target text the "strangeness" of the source text, new trends that have emerged after the development of cultural and post-colonial studies focus on the way in which power asymmetries influence the translation process and, accordingly, the even more significant role that translators play in this context (Cotter, 2014, p.16). Thus, we may speak about a new power turn: despite the fact that he/she belongs to a minor language/culture, the translator pertaining to such an area may have an impact that is by no means insignificant. This is also the case of Blaga - the translator during the first years of communism in Romania.

\subsection{Historical context: on the "golden age of translation" in Romania}

Translation is a social product; in order to fully understand translation policies, a socio-linguistic approach is needed in Translation Studies. In this respect, Peeters (1999) defines the translator as a socio-linguistic actor, whose task is to facilitate understanding between foreign speakers (p. 261), an actor who, nevertheless, has to cope with the constraints of his/her era.

A prime example of the way in which the social and ideological requirements specific to a certain era have an impact on translators is represented by translations performed in Romania immediately after the establishment of the communist regime. The Russification of Romania was based first of all on a linguistic policy, but, broadly, it aimed to align the whole society to the standards of Soviet communism. Translation itself became, in this context, an important tool of Sovietisation:

The new Romanian regime initiated a massive project of translation, both technical and literary, and coupled it with a politics of language and an ideology of reading, all of which was meant to bring the new Romania into line with the Soviet Union. The translation project was the cultural counterpart of power consolidation and national modernization, a golden age meant to usher in the luminous dawn of communism.

(Cotter, 2008, p. 841-842)

In our view, this massive project has two components: on one hand, a linguistic policy, aiming to modify the internal structure of the Romanian language in order for it to resemble as much as possible the Russian language ${ }^{10}$, by replacing Latin terms with Slavic ones and introducing a style full of clichés, devoid of substance (which we call today "wooden language"), and, on the other hand, a translation policy, meant to "carry" Soviet realities in Romania (thus, through alienation and foreignization strategies). Within this huge project, translation becomes a manipulation tool, meant to implement the Soviet model at a linguistic, cultural and political level. Cotter (2008) even speaks about a "colonization" of Romania by the Soviet power, the aim being to alienate the Romanian nation from its own identity (p. 842) ${ }^{11}$. In such a context, the relationship between alienation and assimilation as translation techniques changes, as ethnocentric translation becomes, paradoxically, a strategy of resistance to the Soviet policy.

\footnotetext{
7"The minor is a model of decentering one language by turning toward multiple languages" (Cotter, 2014, p. 146).

8“[...] the discipline of translation studies has paid scant attention to this area. [...] One result of avoiding the challenges of theorizing smaller languages is that the theoretical models we do have are often better suited for the major than the minor" (Cotter, 2014, p. 15).

${ }^{9}$ The translation we suggest for the term "étrangeté" used by Berman (1995).

${ }^{10}$ As an example, Cotter indicates the replacement in the name of the state ("România") of the letter "â", of Latin origin, with "i”, of Slavic origin (Cotter, 2008, p. 842).

11 "In 1940s and 1950s Romania, colonization strove to sovietize Romania, that is, to foreignize Romania from itself" (Cotter, 2008, p. 842).
} 
Concretely, the new linguistic and translation policy is applied through the creation of some ad hoc publishing houses (Cartea Rusă [The Russian Book], Editura de stat pentru literatură și artă [The State Publishing House for Literature and Art]) and through the designation of the types of source texts: legal texts, technical handbooks, scientific papers and Russian literature. Progressively, the translation policy has also accepted publications belonging to some canonical Western writers, such as Shakespeare, Goethe, Rabelais. The phrase used by Sean Cotter in order to define this era ("the golden age of translation in Romania") is only half-ironic: in fact, in the 1950s, the number of translations exceeded by far the number of original Romanian language publications ${ }^{12}$.

In order to illustrate the new linguistic and translation policy, Sean Cotter evokes important characters of the period, such as Iorgu Iordan and Tudor Vianu. On the occasion of a speech held at the Central Committee in 1949, Iorgu Iordan pleads for a broader use of the pronouns "I" and "we", in order to create a discursive contrast with "they" and "you" and to emphasize the class struggle, even if in Romanian the use of such pronouns is not compulsory:

The people of the Party are fighters. They permanently take into account the enemies and opponents of the working class from all over. [...] This continuous presence of the class enemy, linguistically expressed by "you" or "they", [...] inevitably compels us to use the pronoun "we", even if, strictly from a grammatical perspective, this pronoun is useless. "We" valiantly and violently opposes "you" or "they" and its frequent use creates the effect of a repeated strike against the opponent.

(Iordan, 1949, p. 17; our translation)

Such an approach corresponds to the linguistic policy of the new regime. In what concerns the translation policy, Iordan states that it aims to widely impose the Russian language in Romania (the translation being just an intermediary step in this plan):

This situation will last for a while, until the moment when the knowledge of the Russian language of the Romanians will have the quantitative and qualitative consistence needed in order to allow them to use it commonly in speech, in order to communicate with one another, but also in relation to people whose maternal language is Russian.

(Iordan, 1949, p. 17; our translation)

Translation through alienation is, therefore, the way in which the Russian language should have become popular at a general level, aspect also underlined by Sean $\operatorname{Cotter}^{13}$. Thus, translators become pioneers of the linguistic and ideological transformation that was going to occur in Romania.

The source-oriented translation policy is also endorsed by Tudor Vianu. Prominent figure in those years, having also signed the preface of the translation of Faust into Romanian by Blaga, he declares:

A translation has as only aim that of bringing great writers closer to us and of helping us to get closer to their world. An artistic translation opens new perspectives to an unknown universe and makes chords that did not vibrate before resound in our soul. A translation should be a journey to a foreign country.

(Vianu, 1956, p. 275; our translation)

Of course, if we did not know the context in which Tudor Vianu exposed his translation ideology, his discourse would resemble "the reader brought to the author" metaphor, pertaining to Schleiermacher, or

\footnotetext{
12“Translations continued to be published in large numbers through the 1950s, competing with and exceeding the number of original Romanian works published" (Cotter, 2014, p. 13).

13 "Foreignized translation is a middle state, between Romanian and that language's eventual replacement by Russian" (Cotter, 2014, p. 35).
} 
the source-oriented approach preferred by Antoine Berman. Nevertheless, knowing that this foreignizing translation policy was part of the project of sovietising Romania, the discourse of Vianu is not at all innocent: its aim was, in the terms of Sean Cotter, "to renounce nationality" ${ }^{14}$.

On a practical level, the number of translators from Russian into Romanian at that time was not sufficient in order to meet the requirements imposed by the translation policy described above. As a result, a compromise solution was resorted to: namely, the collaboration between a Romanian translator, most frequently a renowned author ${ }^{15}$, and a "stylist" (sic), whose task was to adapt the translated text to the topic and linguistic constraints of Russian (Cotter, 2008, p. 849). Further on, the aim would have been to have a single translation specialist, fulfilling the tasks of translator and stylist, once Russian was broadly spoken by the Romanian population (Cotter, 2014, p. 41). Until then, translation was a key instrument in the implementation of the new linguistic policy. This is why Sean Cotter compares the sovietising translation policy applied in Romania during the 1950 s to a labour camp ${ }^{16}$.

\subsection{The "Venutiparadox": the theory of the "translator's invisibility"-reversed in the case of minor languages}

Taking into consideration the social and ideological environment existing in Romania during the 1950s, a decade during which many translations were performed "in bulk", based on the compulsory preservation in the target language of the traits specific to the Russian language and culture, the classical theories we encounter nowadays in Translation Studies do not apply or should be reconsidered. Sean Cotter also considers that translation theory, as we know it today, neglected or even ignored translations performed in minor areas, where the power ratio is different, particularly when a specific translation policy is imposed by the historical and social context (this is also the case of Romania during the Soviet occupation). In other words, Translation Studies should also analyse this power balance from the perspective of colonized States and not only from the perspective of colonizing States, whose language is, in most cases, a central language. Translation turns out to be, once again, a social product, subject to external constraints, while the translator becomes a prisoner of his/her era.

Sean Cotter proves that the paradigm established by Venuti (1995) is reversed in the case of translations performed in minor areas. The example chosen is represented by translations performed in Romania during the first years of the communist era, when exocentric translation became a manner of alienating the nation from itself: "The imposition of the Soviet power followed a thoroughly foreignizing strategy, precisely the opposite association that translation studies would predict for hegemony" (Cotter, 2014, p. 29). The association established by Venuti (1995) between exocentric translation and resistance, on one hand, and ethnocentric translation and hegemony, on the other hand, is questioned by Sean Cotter in the case of translations performed in Romania, a minor area, during the 1950s: "Applying his terms to 1950s Romania reverses their ideological polarities, associating foreignization not with resistance, but with hegemony" (Cotter, 2014, p. 32-33). Thus, paradoxically, in the case of minor languages, translation that preserves the traits specific to the target language and levels the marks linked to the strangeness of the source culture becomes a mark of resistance.

We consider that the work of Sean Cotter represents a new approach in Translation Studies, inviting researchers to examine translations from the perspective of minor languages and cultures and to take into account the historical and social context. Purely theoretical paradigms established in the field (faithfulness vs unfaithfulness, foreignization vs domestication, the strictly linguistic resistance of the source text to translation; see Ricœur, 2004) must be reconsidered and applied, with certain limits, on a case-by-case basis. Moreover, current translation scholars, having noticed that classical paradigms are not universally valid, have started to focus, for the moment to a small extent, on translations produced in minor languages,

\footnotetext{
14 “《Renouncing nationality » could be better described as a literal and metaphorical process of translation, in which Romanian public discourse was transformed through translations from Soviet texts” (Cotter, 2014, p. 8).

${ }^{15}$ For example, Tudor Arghezi has translated fables from Russian using the French version; Ion Barbu has translated some Shakespearian works; Lucian Blaga has translated Faust by Goethe, but also other poems from the world literature (Cotter, 2014, p. 14).

16“Translation can have as literal an effect as a prison labor camp” (Cotter, 2014, p. 36).
} 
for example those from the ex-Soviet area (see Schippel \& Zwischenberger, 2017), which is a first step in this direction.

In what concerns Blaga - the translator, we consider that the theory of Sean Cotter according to which the foreignization vs domestication paradigm is applied differently in Romania during the 1950s may be continued and deepened through the addition of certain key elements. We notice that the well-known phrase established by Venuti, namely "the translator's invisibility", does not apply in the case of Blaga: the renowned poet and philosopher was, during the last years of his life, only a translator. If his literary and philosophical work was prohibited, he found a refuge in translation, as translation was not subject to the same censorship mechanisms. On the other hand, the success enjoyed by the translation of Faust proves once again that Blaga had become, in the words of Sean Cotter, the national translator. It was not the translated work that stirred public interest, but the fact that the translation had been performed by the Romanian poet and philosopher so loved by the public and isolated by the new political regime. Thus, the translator acquires a voice: the translator becomes visible.

Also, the work of Sean Cotter does not approach, in our opinion, two crucial aspects that would support his theory even more: on one hand, in Faust și problema traducerilor [Faust and the Issue of Translations], but also in the preface of Din lirica universală [Poems from World Literature], Blaga himself exposes his preferred translation strategies, based on "annexation and assimilation" (see Blaga, 1957b, p. 5); therefore, he favours ethnocentric translation. Hence, his ideology of translation is materialized through specific strategies at the textual level. On the other hand, analysing the historical, political and social context that has a major impact on translations during the first years of communism in Romania, Sean Cotter speaks about Blaga - the translator, but he almost ignores Blaga - the translation theorist. However, taking into account the theoretical and conceptual considerations we find not only in Faust și problema traducerilor [Faust and the Issue of Translations], but also in other metatexts belonging to Blaga, we notice that the translator is also a translation theorist, who has a specific approach to the translation process. His perspective on translation supports the idea of translation as a way of being (literally speaking - as a way of making a living, and metaphorically speaking - as a way of existing, of continuing the intellectual activity), but also as a way of resistance during those difficult years.

Thus, we consider that an analysis of what we call "the Venuti paradox", namely the way in which the theory of Lawrence Venuti is reversed in the case of translations performed by Blaga in Romania during the 1950s, is necessary. This reversal takes place, on one hand, because the "invisible" translator becomes visible and, on the other hand, because annexation and assimilation as translation techniques become a way of resistance to the new regime.

\subsubsection{Lucian Blaga: the translator abandons his invisible position}

Historically speaking, the translator was always assigned a secondary role, being seen as a humble servant who "carries" the idea of others from the source language into the target language. We mention, in this respect, the well-known response of the geometer from the Persian Letters of Montesquieu, who expresses his amazement when he finds out that his conversation partner has been a translator for twenty years: "What, Sir! [...] have you spent twenty years without thinking? You speak for others, while they think for you" (Montesquieu, 1956, p. 223; our translation from French). Aside from the irony related to the distrust targeting the translator, we encounter the bias according to which translating is not at all a creative process (for the geometer of Montesquieu, translating means, ironically speaking, not thinking at all!). We may also mention the well-known phrase "traduttore traditore", associating the translation process and treachery, or the "beautiful but unfaithful" ("les belles infidèles"), a trend meant to embellish translations in order to please the reader, observed in France during the $17^{\text {th }}$ century. Thus, the portrait of the translator is not at all flattering over time. The translation process was (and, at times, is) considered a secondary literary practice, while the translator is, most of the times, invisible, by his/her own choice or due to external reasons.

Paradoxically speaking, this paradigm of "the translator's invisibility" is not valid in the case of Blaga: 
from a secondary practice, translation becomes a technique of resistance through the subtle means used by the translator. In order to fully understand what were the factors that have helped the translator abandon his "invisible" position, we refer again to the historical and social context existing in Romania during the first years of communism. As a result of the new linguistic and translation policy, translators in general became more important than Romanian authors:

[...] translation offers young intellectuals steadier and better-paid work than other forms of publishing. The importance of translation only increased under communism; translators were well paid and canonical figures, as much those currently in favor as those who were censored, were enlisted.

(Cotter, 2014, p. 3)

Therefore, the power balance author vs translator is changed primarily as a result of the new sovietisation policy: many of the renowned Romanian authors became, whether they wanted or not, translators. This is also the case of Blaga, who, during the last part of his life, devotes himself to translation, an activity that represents an important financial and moral support, being, in fact, the only activity tolerated in his case by the communist regime.

Still, Blaga did not see in translation a chore and did not discover his calling as a translator during those years. Fascinated by the world literature, he published in 1928 in "Gîndirea" two translations of poems pertaining to the Russian poet Sergei Yesenin: literary critics of the time have noticed the stylistic print of the translator in the lyrics of Yesenin (see Vatamaniuc, 1977, p. 482-485). One can notice that the poet and translator has preferred assimilation and annexation as translation techniques since an early age.

The translations published in the volume Din lirica universală [Poems from World Literature] have been performed, according to the confession of Blaga from the metatext entitled În loc de prefață [Instead of a preface], since the Second World War:

The majority of translations ("tălmăciri”") gathered in this collection of poems have been in the work, continuously or not, since 1943, when one could still hear cannons firing. These transpositions are exclusively due to the enthusiasm with which my soul has approached the texts presented to me.

(Blaga, 1957b, p. 5; our translation)

We notice the terminology used by the poet-translator, who calls his work "tălmăciri”" (an older term used for "translation") and, respectively, "transpositions", which proves already that Blaga possesses a specific philosophy on translation. His intention to publish a collection of poems translated from the world literature is to be found in a letter addressed in 1944 to the literary critic Pompiliu Constantinescu:

I intend to publish a collection of poems translated from the world literature. Thirty poems. I think that you will like them. There are Egyptian, Chinese, Greek, German, French, English and Russian poems and two poems from the early people. Some of them are stunning.

(apud Cenuşă, 1989, p. 272; our translation)

In what concerns the working method, Blaga has resorted, sometimes, to texts already translated, probably in central languages, such as French and German, as he testifies in the same metatext entitled $\hat{I}$ loc de prefață [Instead of a Preface]:

\footnotetext{
b As the term "tălmăcire" does not have a specific English equivalent aside from "translation", we have mentioned it in brackets.
} 
I have gleaned from foreign authors and anthologies, as best as I could and where I could. For the transposition, I have used texts written in the original language, but also translations into other languages, when the language of the original texts was totally unknown to me.

(Blaga, 1957b, p. 5; our translation)

Again, the work of the translator is called "transposition"; later on, in the metatext entitled Faust si problema traducerilor [Faust and the Issue of Translations], the poet-translator provides a definition of the translation process, based on this terminology.

Aside from the collection Din lirica universala [Poems from World Literature], published in 1957, Blaga also publishes in 1958 the volume Din lirica engleză [English Poems] and translations of some larger writings (among which two books of Lessing). Nevertheless, the translation that helps Blaga become "the national translator", in the words of Sean Cotter, is Faust by Goethe, considered over the years "one of the most luminous translations into Romanian" ${ }^{\text {" }}$, according to Jean Poncet, one of the translators of the poetry of Blaga into French. The importance of this translation has remained unchanged over time, even if other translations of Faust into Romanian were published in the meantime, such as the translation signed by Ștefan Augustin-Doinaș. The translation of Faust by Blaga is considered a reference even today, having been republished recently by Humanitas Publishing House in Bucharest ${ }^{18}$.

The translation of Faust involved an exceptional effort not only due to the size of the source text, but also due to the stylistic difficulties that Blaga describes in the metatexts analysed by us in this paper. The fact that he was familiar with the German language and culture and the importance of the source work determine Blaga to see this project as a moral duty:

My knowledge of German, the philosophical training that I have and the experience as a poet that I have acquired over more than three decades of literary activity encourage me to believe that I could carry out such a project. The work to translate is difficult and the effort required by this project is huge. But Faust is for me an old issue.

(apud Bălu, 1999, p. 192; our translation)

The proof that Blaga has abandoned his invisibility as a translator is the reception of his translation by the general public. Despite some critics such as Mihail Isbăşescu, who stated that the translation of Blaga was "unfaithful" to the source text, that it had a larger number of verses compared to the original and that it was impregnated by the poetic style of the translator (Bălu, 1999, p. 269), the public has received the translation of Faust with unexpected enthusiasm. It is, in fact, the translation that enjoys the best reception during those years: it is printed in 25 thousand copies; in Bucharest, the book runs out of stock in three days, while in Cluj, the shelves are emptied in a few hours (Cotter, 2014, p. 48). The reputation of the translator, rather than the importance of the translated work, explains such a reception.

The success enjoyed by the translation of Faust allows Blaga to give speeches and to write papers on literary translation. The conference "Meetings with Goethe", held at the Central Library of the University of Cluj, represented a first contact with the public after a long silence imposed to Blaga by the new regime, nine years after he was dismissed from the University and twelve years after his last book was published (Bălu, 1999, p. 315). Blaga presents himself to the public, this time, only as a translator.

The translator, once visible, finds in translation not only an intellectual refuge, but also a way of existence, for himself and for the nation he belongs to:

The public reaction to Faust convinced him of the viability of translation as a mode for public life. The success of his works allowed him to give speeches and interviews and publish articles on translation. With these publications, Blaga pursued his use of translation as an image of

\footnotetext{
${ }^{17}$ In French in original: "l'une des plus lumineuses en langue roumaine".

${ }^{18}$ See Johann Wolfgang Goethe, Faust, translated by Lucian Blaga, Humanitas, Bucharest, 2017.
} 
Romanian culture, his advocacy on translation as a mode for Romania. Thus, his mode and his message are the same.

(Cotter, 2014, p. 81)

Paradoxically speaking, despite the prohibition to publish as an author, translation has allowed Blaga to become visible again during those last years of his life. From the perspective of the new regime, the name of Blaga gave substance to the national linguistic project; ironically, however, his participation in this project allowed him, through annexation and assimilation techniques and through his ideology of translation, to become a symbol of resistance and, probably, the most important translator of that decade.

\subsubsection{Lucian Blaga: ethnocentric translation becomes a technique of resistance}

As we have indicated previously, the pattern suggested by Venuti (1995), based on which exocentric translation would be a dissident practice (p. 148), is challenged by Cotter (2008), who relies in this respect on the case of translations produced in Romania during the first years of communism, insisting that, in this case, "foreignized translation is obedience" (p. 846).

Basically, the way in which Cotter reverses the paradigm proposed by Venuti in the case of minor nations is summarized below:

Venuti:

exocentric translation (foreignization) $\quad=$ resistance, dissidence

ethnocentric translation (domestication) $=$ imperialism, colonization

Cotter:

exocentric translation (foreignization) $\quad=$ imperialism, colonization

ethnocentric translation (domestication) $=$ resistance, dissidence

For minor nations and cultures, therefore, ethnocentric translation, carried out through assimilation and annexation, terms used by Blaga himself, becomes a mode of resistance. In fact, the poet-translator expresses his preference for this translation strategy in the metatext entitled $\hat{I} n$ loc de prefață [Instead of a Preface] at the beginning of the book Din lirica universală [Poems from the World Literature]:

I did not intend to create, in this volume, an anthology of world poetry. Reading and rereading verses chanted in ancient Egypt, during Greek and Chinese antiquity, in black forests in deep Africa, under the Italian or Gallic skies, I felt this burning desire to annex and assimilate in our language some of the most beautiful poems of the world literature. I was not interested in their number. I was only interested in their value. .

(Blaga, 1957b, p. 5; our translation)

For Blaga, translating means annexing and assimilating, transposing the content of the source text using the means and based on the spirit of the target language. This idea is to be found also in one of his aphorisms: "Translating means annexing. A nation can annex another nation, translating the literature of the former into its own language. The annexed nation does not lose anything, while the annexing nation grows and evolves" (Blaga, 1972, p. 177; our translation). This desire to annex and assimilate poems pertaining to various eras and cultural areas is probably justified by the fascination manifested by Blaga for the world poetry and by his admiration of great poets, in particular those in German literature, such as Hölderlin or Rilke. Therefore, translation becomes a transforming experience and a necessary accomplishment:

Translating-I quenched a mighty thirst. Translating-I acquired a new experience. I wanted to see whether poetry could be "carried" from one language into another. Translating-I felt myself growing. As I have chosen only poems that excited me and that, through translation, could become, in a way, mine, ours, could belong to Romanians.

(Blaga, 1957b, p. 5-6; our translation) 
Translating is nothing but the contact with the Other, with the Stranger, according to the meaning Antoine Berman provides to these terms. Or, through translation, Blaga intends to transform this Other in his Self. This explains, maybe, the fact that certain critics have discovered at times in the poetry translated by Blaga the stylistic print of the poet himself.

However, the metatext completely proving the preference of Blaga for ethnocentric translation is his paper entitled Faust și problema traducerilor [Faust and the Issue of Translations], in which he presents a translation methodology. Thus, Blaga thinks that the translator should resort to all resources of the Romanian language, taking into account two components in particular - the popular language and the neologism:

Since the very beginning, I realized that, in order to transpose Faust, I should use all resources of our current literary language. Two important sources were available: the popular language sublimated into literary language, and the neologism. I intended to use in my translation, as needed, local and plastic phrases, full of flavour and creating atmosphere-of popular origin, and neologisms that contribute to the expression of all kinds of abstractions.

(Blaga, 1972, p. 116; our translation)

The translation methodology suggested by Blaga is clearly an ethnocentric one. It is only in this manner that the annexation and assimilation into Romanian of great literary works can take place. The two linguistic sources preferred by Blaga (the popular language and neologisms) should obey a unique conditionbe part of the language spoken at that time:

The condition that I have imposed to these two linguistic sources was the following: the terms resorted to should have been widely used, widely used at least in the language spoken by intellectuals nowadays. Being guided by certain criteria and norms that would protect me from certain shortcomings and excesses, I proceeded.

(Blaga, 1972, p. 116; our translation)

The methodological debate continues with a plea for the use of a comprehensive, widely spoken language and the avoidance of regionalisms in translation:

I did not try to use a rich vocabulary, but to use in a nuanced, unusual way, a vocabulary that is widely spoken by Romanians. I did not intend to use picturesque, rare words, whose meaning should be searched in the dictionary, but a new combination of words, used by the Romanian society as a whole. I have deviated very rarely from this criterion when translating Faust.

(Blaga, 1972, p. 117; our translation)

Thus, we understand that the translator pleads for a natural language, unforced by the new linguistic policy that aimed to transform the order of words, the vocabulary, the linguistic structure and, eventually, to Russify the nation.

Taking into account the complexity of the source work, Blaga considers that its transposition into Romanian could benefit from "the luminous virtues of neologism" (Blaga, 1972, p. 117). He even blames former translators for avoiding neologisms and for using "a language specific to the magazine "Semănătorul" in order to translate a highly intellectual literary work” $\left(1972\right.$, p. 117-118) ${ }^{c}$. Nevertheless, continues the translator, using neologisms when translating Faust does involve specific risks:

Using neologisms in poetry involves, however, a series of issues. The reality is that, for our ears, neologisms create in general a "prosaic" impression. Therefore, the dilemma. On one hand, the

\footnotetext{
"The magazine "Semănătorul" was published in Romania at the beginning of the $20^{\text {th }}$ century and adopted a conservative, traditionalist language.
} 
use of neologisms when translating Faust was necessary for reasons that are related to the high intellectual level of this poetic work and, on the other hand, neologisms still impress our ears in a "prosaic" manner.

(Blaga, 1972, p. 118; our translation)

In order to successfully solve the "neologism dilemma" (Blaga, 1972, p. 118), Blaga resorts again to his ethnocentric philosophy on translation and suggests the use of a compensation technique, through which the "saviour neologism" is accompanied by a local term (which is not obsolete, such as the language used in the magazine "Semănătorul" recalled above). This contributes to the preservation of the poetic level of the source text:

The result of my experiences can be summarized as follows: any neologism currently used, however "prosaic" it would seem, can be recovered for poetry if it is accompanied by a compensating epithet belonging to the genuine Romanian language or if it is combined in general with a local, plastic and savoury phrase. Of course, in any language there are words that are poetical in themselves, due to their resonance and to the meaning they have. But poetry is born not only from and through isolated words; poetry is also born through the combination of words. And here, there is plenty of room for neologisms. Of course, the use of the saviour neologism combined with a local, Romanian word depends, in the end, on the linguistic creative power of the translator or of the poet.

(Blaga, 1972, p. 118; our translation)

The implementation of this compensation technique, defined as the combination of neologisms and local Romanian terms, depends on the creative power of the translator, which means, of course, that the translator is a creator. However, the ethnocentric perspective of Blaga on translation is not limited to the introduction of a methodology based on assimilation and annexation strategies, but it also involves, as one may see, a philosophy on translation and translators. Thus, Blaga is not only a translator, but also a translation theorist, a topic we develop in the following section.

In his metatext Faust și problema traducerilor [Faust and the Issue of Translations], we find examples involving the localisation of culture-bound terms specific to the source language through ethnocentric translation strategies. These culture-bound terms are "certain geographical names or terms belonging to German mythology" (Blaga, 1972, p. 121). Blaga chooses to adapt them to the Romanian culture and mythology:

I have avoided on purpose names and terms as often as the text allowed me to do this. It is the case, for example, of certain places from Harz mountains, of Brocken or Blocksberg. In the case of the landscape in which the valpurgical night takes place, I have resorted to more general terms in the vocabulary of our shepherds, using words such as "plaiu", "măgură", "Bătrîna”, "Ciobanul”, etc. The Blocksberg itself simply becomes in my translation "muntele nebun", a name suggested to me by an epithet accompanying the Blocksberg in the original text. In the case of terms belonging to German mythology, which are not at all appropriate in a Romanian translation, I have searched for corresponding names in our folk mythology. Thus, I have used in my text the name "crasnic", which means a crossbreed of devil and woman.

(Blaga, 1972, p. 121-122; our translation)

Of course, certain contemporary critics would consider that this ethnocentric translation is "unfaithful" to the original text; other critics would go as far as to not consider it a translation, but an adaptation of the source text to the realities of the target culture, because the reader might have the impression that the events in Faust take place in Romania. However, the choice of such a strategy must be analysed based on the historical context of those years: on one hand, ethnocentric translation is the foundation on which Blaga builds his translation ideology and, on the other hand, it can also be seen as a technique of protest, of resisting the rigors of the new linguistic policy, intended to alienate the nation from itself. 


\section{Lucian Blaga - translation theorist avant la lettre}

In Faust și problema traducerilor [Faust and the Issue of Translations], Blaga - the translator defines the general principles of a translation methodology that preserves the specificity of the Romanian language, but his discourse is not limited to the translation of Faust: in the second part of his metatext, Blaga turns out to be a translation theorist. Sean Cotter recognizes, in fact, that the poet and translator had a major role in the cultural life of those years: "Blaga is not only the most visible translator of this period; he is also the most dedicated and profound thinker on translation and national culture" (Cotter, 2014, p. 24). The general public knew Blaga as a poet and philosopher of culture, but he is also a philosopher of translation.

In order to present the ideology of Blaga on translation, we emphasize the fact that the poet rarely used in his metatexts the term "traducere" ("translation") in order to designate his work: the preferred terms are "tălmăcire" and, respectively, "a tălmăci”, whose meaning is closer to interpretation, deciphering than to translation ${ }^{19}$. Blaga might prefer these terms because he assumes the modest role associated to translators since ancient times, but, more likely, because he has a specific ideology on translation. The verb "a tălmăci" becomes, in the case of Blaga, the process of translating/transposing/interpreting or its result. This verb is also present in the poetry of Blaga. For example, in the poem Stihuitorul [The Poet], Blaga associates the creative effort of the poet to the labour of translation; for him, the two activities are the same: the poet only "translates" into Romanian the song of his own heart ${ }^{20}$. Thus, translation and literary creation are one and the same.

Besides the ethnocentric strategies, the idea of translation as interpretation is the other component of the translation ideology of Blaga. He sees in translation an interpretative act, a deciphering or a re-creation. Since the very beginning of his paper Faust și problema traducerilor [Faust and the Issue of Translations], Blaga speaks about the "suffering of the transposition" that encouraged him to present his ideology on translation:

A translator, whose soul was transformed by the the wildfire of transposing Faust, has indeed something to say about the issue of translating poetry from one language into another, and in general about the issue of translations, in the context of our literature. [...] He who did not experience himself the suffering of transposing one poem from a foreign literature into our language would not realize how difficult and complex the translation issue is.

(Blaga, 1972, p. 113; our translation)

Blaga emphasizes that translation as a creative act, that involves labour and "suffering", has been considered, historically speaking, an unimportant, secondary activity. In this respect, he draws a diachronic analysis of poetry translation in the Romanian area: he considers that "our literature possesses only very few high level translations from the world poetry” (Blaga, 1972, p. 113) because, during the process of consolidation of the literary Romanian language, canonical poets (such as Eminescu or Alecsandri) devoted themselves only to original literary creation, while "translations did not stir much interest or, even worse, were performed by amateurs, who are always present in this field, which provides so easily the illusion of creation" (Blaga, 1972, p. 114). We notice here, once again, the ethnocentric philosophy of Blaga on translation (literary translations are part of the national literature) and his preoccupation for a standard of quality in translation.

Deploring the precarious situation of literary translations in Romania, Blaga recalls some of the previous translators of Faust (such as George Coșbuc or Ștefan Octavian Iosif) who, however, "did not produce the masterpiece translation" (Blaga, p. 114). By comparison with other minor nations, such as the Hungarians, who already possessed a "literary patrimony" and successful translations, Blaga identifies in the

\footnotetext{
${ }^{19}$ See dexonline.ro: a tălmăci (among other meanings) - 'to translate', 'to transpose', 'to interpret', but also 'to explain', 'to clarify', 'to clear up', 'to decipher'.

${ }^{20}$ See Lucian Blaga, Stibuitorul, in Blaga (2010, p. 456).
} 
Romanian area a crisis of literary translation in the mid- $20^{\text {th }}$ century: "The situation is so deplorable that «translation » has become in our country an issue for specific reasons that do not exist anymore in the case of other nations" (Blaga, p. 114).

Therefore, translation is crucial for the consolidation of the Romanian language and literature, as any literature is, inter alia, a mirror of the world literature:

Let us not forget that a literature, being entirely aware of its mission, does not aspire to become only a collection of original works, no matter how impressive the size of such a collection would be. Any literature must also become a mirror of the world literature.

(Blaga, 1972, p. 114; our translation)

There seems to be no difference between the creator and the translator of literary works.

One of the sources of this crisis of literary translation, considers Blaga, is the lack of coherent thinking on translation. In order to support this argument, he recalls the translation of the Bible, fundamental for the establishment of world literatures:

Moreover, the mere fact that the vast majority of modern European literatures begin with a "translation", the translation of the Bible, should represent, we believe, a sufficient reason to consider the "translation" an intellectual activity.

(Blaga, 1972, p. 115; our translation)

Besides an appreciation of translation as an intellectual activity, Blaga considers that this crisis could be solved through a stronger involvement of writers and poets in the translation project, following the German pattern (Goethe, George or Rilke also devoted themselves to translation). In this respect, Blaga welcomes the recent involvement of some canonical writers in the translation project:

The despicable distrust in translation manifested by Romanian writers was present until recently, when, due to higher-up initiatives, an encouraging turn in this respect has occurred. We will shortly have good translations of the world canonical literature.

(Blaga, 1972, p. 115; our translation)

After these general considerations regarding translation as an intellectual activity and the crisis of literary translation in the Romanian area, Blaga presents the reasons for which he has accepted to translate Faust (among which his love for the German language and culture), the preparatory steps (analysis of previous translations, that turned out to be useless), as well as the translation methodology we have examined above.

In what follows, Blaga presents the translation difficulties he dealt with in his work, among which the plurality of poetic forms and the overlapping stylistic features. These difficulties seemed, at the beginning, unbeatable:

The issues involved by this translation were overwhelmingly complex. The difficulties I have encountered often seemed unbeatable. The multitude of poetical forms, which combine in this literary work like the architectural elements of a cathedral built during hundreds of years, with generational changeovers and stylistic overlapping, was disheartening at times, but it was also a fierce, striking incentive for me to complete the work I intended to achieve.

(Blaga, 1972, p. 116; our translation)

Blaga explains the stylistic variety of the work of Goethe, which includes preromantic, classical or neobaroque elements, by the fact that the author has dedicated a long period to the creation of his masterpiece: "The styles of Goethe's various creative ages are to be found in the structure of his work as geological strata in the crust of the Earth" (Blaga, 1972, p. 120; our translation). Blaga endeavoured to confer to 
his translation a uniform stylistic character, resulting from "an interference area" between the style of the author and his own style. Such an interference area where the two stylistic structures combine indicates the existence of a style proper to the translator (and the translator, in the opinion of Blaga, should also be a poet). This is the moment when the poet-translator provides a definition of "poetic translation":

A poetic translation comes into being in an area of interference between the stylistic traits of the original work and the stylistic traits pertaining to the poet-translator. As hard as the translator may try to depersonalize himself, this interference of structures occurs beyond any doubt.

(Blaga, 1972, p. 119; our translation)

Here, by "poetic translation" we understand "poetry translation", but also "a translation that preserves the poetic nature of the source text". Such a conception on poetry translation from a stylistic perspective proves the modern nature of his thinking: Blaga not only identifies translation difficulties and provides solutions, but also considers that translation comes into being only through the overlapping of the style of the author and the style of the translator. Thus, stylistic interference exists by default in translation. In order to support this argument, Blaga proves that he is familiar with the most recent theories of the time:

European literary criticism comprises some recent conclusive studies proving that stylistic traits, tendencies, habits specific to a poet can be analysed mainly based on translations of works originally written in other languages. This is natural, because one can compare translations to original works, and the latter, from various perspectives, have another stylistic pattern.

(Blaga, 1972, p. 119; our translation)

Blaga states that, while translating, the poet-translator does not depersonalize himself, does not give up his own style and does not become a mirror of the author. Based on his ethnocentric philosophy on translation, he claims that the stylistic imprint encountered in the target text is purely accidental:

In what concerns the language into which I have translated, I have stated that it bears, of course, the imprint of the poetic language of the translator. I did not want this on purpose. On the contrary, the result was obtained unwilfully. In other words, I did not intend to impose my style when translating. My intention was to depersonalize myself as much as possible and to assimilate Faust into the Romanian literary language in general.

(Blaga, 1972, p. 122; our translation)

The objective of such a translation, which is the result of stylistic interference, is the assimilation of the source text into the Romanian literature and culture. The issue of stylistic interferences in translation is also found in recent translation studies: for instance, the work of Mathilde Vischer, La traduction, du style vers la poétique: Philippe Jacottet et Fabio Pusterla en dialogue [Translation: from style to poetics: Philippe Jacottet and Fabio Pusterla in dialogue], analyses the issue of stylistic interferences that are present when a poet translates another poet. This only confirms that Blaga has a modern approach on translation.

In the same metatext, we find a relevant definition of poetic translation:

A poetic translation, valid in itself and by itself is, according to all its objective and subjective terms, a "re-creation" and not a literary transposition form one language into another. Great translations, translations that count, belonging to various literatures, are "poetic equivalents" and not mere "translations". The Germans call this type of translations "Nachdichtung" or even "Umdichtung". My translation is a "Nachdichtung".

(Blaga, 1972, p. 119; our translation) 
This is the passage summarizing the entire translation ideology of Blaga: successful poetic translation is a re-creation, a poetic equivalent of the source text, and not a mere transposition, the action of carrying meaning from one language into another. According to Blaga, poetic translation occupies a special place, being closer to adaptation (Nachdichtung) or poetic transformation (Umdichtung). Thus, he recognizes that his translation is an adaptation or a "poetic equivalent" of Faust in Romanian and not a "notary translation", which means an "accurate" translation. A "notary translation" observes stricto sensu the letter of the source text, but does not take into account its spirit: "during my activity as translator of Faust I strived to propose a poetic equivalent, and not a notary translation" (Blaga, p. 123), because "an essential condition of a good translation is not to resemble a translation" (p. 121). In the case of Blaga, translation is in itself a literary work, being the equivalent of the original text in the target language and culture. Due to his modern conception on poetry translation, Blaga is close to current translation theorists, such as Henri Meschonnic, who claims that translation is a text in its own right, Eugene Nida, who introduced the concept of "dynamic equivalence" or Marianne Lederer, one of the founders of the interpretative theory, who states that any translation is an interpretative act. Also, Blaga speaks about the "resistance" of the source text to translation, especially because of the poetic signifier: "Poetry is an art of playing with words and, among other things, it is also a function of the sonority implied by words. This is why poetry resists so incredibly to translation" (p. 124). Paul Ricœur will speak later about the double resistance, of the source language and of the target language.

Towards the end of his paper, Blaga comes back to the definition of poetry translation. If poetry is considered an art of playing with words, poetry translation is, in turn, an art located between interpretation and creation:

Poetry has been defined as an art of playing with words. A notary translation of poetry is never poetry. Poetry translation is an art in itself and by itself, more that any interpretative art. Poetry translation is an art located between interpretative arts and creative arts. Poetry translation is in itself and by itself poetry or it is nothing.

(Blaga, 1972, p. 123; our translation)

Interestingly, the rhetoric of Blaga in this passage bears a striking resemblance to the rhetoric of Henri Meschonnic, when he pleads for the hermeneutics of translation. Anticipating, somehow, the theory of the latter related to translation as an act of writing, Blaga states that poetry translation is poetry itself or is nothing. The interpretation of the source poem and the creative power of the poet-translator are the two techniques through which poetry can be transposed into the target language.

Continuing this analogy, if poetry translation is re-creation through interpretation, through deciphering ("tălmăcire"), the genuine translator becomes creator in his own right, rivalling the author himself: "I cannot imagine a poetry translator who does not love his work like a true original creation. Thus, the translator should compete with the original" (Blaga, 1972, p. 124-125). The potential failure of the translator in this combat is also taken into account, but a possible remedy preventing such a failure is the use of compensation techniques, especially in the case of large-scale literary works, such as Faust:

The experience I acquired with larger poems and with Faust encourages me to believe that the attempt to translate large-scale poetry works has, of course, other chances. In his effort of translating large-scale poetry works, the translator benefits from a real possibility to compete with the original. In the case of a larger poem, the translator can find instances where, due to the language into which he translates, failures from certain parts may be compensated by achievements in other parts.

(Blaga, 1972, p. 121; our translation)

Compensation as a translation technique is meant to alleviate inherent losses sometimes resulting from the incongruency of languages and cultures and allows the poet-translator to manifest his creative power, 
"competing", thus, with the author: "And, in order to save a poem in translation, we often need a single victory of the translator over the author" (Blaga, 1972, p. 124). Sean Cotter goes beyond the metaphorical meaning of this fight and places it in a larger political and ideological context:

Rather than provide a poem to shape the language that shapes the culture, Blaga provides a translation to do so. A translation, however, will not shape the culture in the same way. It will not suggest that a culture coalesce around the image of autochthonous genius; rather, it suggests that a culture embrace the influence of foreign culture as a source of transformative energy.

(Cotter, 2014, p. 83)

A translation that shapes the culture is, as we have established, the result of an ethnocentric strategy and of an ideology on translation as an artistic interpretative act, as re-creation. Due to the high level of conceptualization, Blaga is, perhaps, one of the first translation theorists in the Romanian area.

\section{Conclusions. Is there a specific tradition in Romanian Translation Studies?}

The question on which our approach is based refers to the existence of a specific tradition in Romanian Translation Studies. Of course, we do not intend to provide here an ultimate answer. However, we draw attention to an important issue: the existence of metatexts of translators, that may include an ideology of translation and may even anticipate certain directions existing nowadays in Romanian Translation Studies. This is also the case of the metatexts of Blaga, in which he reveals his preference for ethnocentric translation and his perspective on poetic translation, which he considers an interpretative and re-creative act. We believe that these metatexts were not sufficiently analysed by current translation scholars, perhaps also because "in particular in Blaga's case, the publication of works that had been censored during that decade overshadowed the importance of his uncensored translations" (Cotter, 2014, p. 6). However, the very analysis of such texts may turn out revealing not only for identifying an ideology on translation, but also for detecting the mechanisms through which translation, through specific strategies, becomes an act of rebellion against an alienation-based regime. Any translator who is fully aware of the importance of his work is also, in our opinion, the owner of a philosophy on translation and is, therefore, a potential translation theorist.

Of course, we cannot speak about the existence of translation research in Romania during the 1950s, when Translation Studies were still part of linguistics and purely theoretical debates referred to topics such as translation possibility/impossibility or faithfulness/unfaithfulness. Nevertheless, a reflection on translation existed since ancient times, long before Translation Studies became a field of research; in this respect, we may name Cicero, Horatius, Saint Jerome, Saint Augustine, etc. In the Romanian area, according to Hélène Lenz, Nicolae Milescu (Spătarul) would be the first translation theorist:

In what concerns the rhetorical question asked by Georgiana Lungu Badea in her paper from 2013 entitled Romanian Ideas and Meta-ideas, "Can we speak about Romanian Translation studies?", we consider that the answer is affirmative, and we refer in this respect to Nicolae Milescu [...]. The work and personality of Milescu [...] represent without any doubt the first step of a Romanian reflection and practice of translation.

(Lenz, 2017, p. 132; our translation)

The reflection of Blaga on literary translation is also in line with this view. In the words of Magda Jeanrenaud, this reflection is not unique during those times:

The Romanian tradition in translation studies seems to have developed within a recurrent theme of the type "how I translated the..." (an allusion to Blaga, 1957), "interpreting..." (Porumbacu, 1951), and "the art of translating" (starting with Vianu, 1956, or Cassian, 1981). It is no surprise 
that the reflection on translation was considered part of comparative literature, of aesthetics, or history of literature, taking into account that the English formula Translation Studies and the French traductologie had not been coined yet.

(Jeanrenaud, 2015, p. 5)

In what concerns current Romanian Translation studies, Magda Jeanrenaud and Georgiana Lungu-Badea both agree that it has followed the Eurocentric trend and it has adopted theories from the Western and North-American areas ${ }^{21}$. The former even deplores a too obvious Eurocentric trend and the lack of a visible reflection on translation from the perspective of minor languages:

In my opinion, however, the concept of "Eurocentrism" should have also been carefully and thoroughly reconsidered, in order to reinstate its richness and variety: whereas, within the European field, influence networks and symbolic power fields are structured around the "great" cultures, disseminated by "central" languages, one should also examine the reactions to translation and the reflection surrounding it emitted by "small" cultures and conveyed by "peripheral" languages.

(Jeanrenaud, 2015, p. 1-2)

Thus, there is a centre vs margins dichotomy in translation, but there also seems to be an analogous dichotomy in Translation Studies. This visibility gap between "central" Translation Studies and "marginal" Translation Studies is, once again, the result of an unequal power balance and may be reduced through the identification of local traits, through the analysis of translation trends existing during a forgotten era (the communist period in Romania) and, also, through the attentive examination of metatexts produced during that era. This idea is also emphasized by Magda Jeanrenaud:

In my opinion, precisely the interest for "practical theory" was part of Romanian translation studies specificity, just like the debate on fidelity/freedom in the context of the period before 1990. I also believe that they disappeared under the pressure of the "centre" or the "centres", which brought along other themes, relating to which researchers wanted/had to have a standpoint.

(Jeanrenaud, 2015, p. 12)

Therefore, if translation is a social product subject to the rigours of history, translation theories are also the conjunctural result of tensions between the centre/centres and margins. In this regard, a translation analysis from the perspective of a minor nation may turn out to be revealing.

\section{Bibliography}

Bălu, I. (1999). Viața lui Lucian Blaga [The life of Lucian Blaga], $4^{\text {th }}$ vol, "Libra" Cultural Foundation, Bucharest.

Berman, A. (1995). Pour une critique des traductions: John Donne, Gallimard, Paris.

Blaga, L. (1957a). Cum l-am tradus pe Faust [The Way I translated Faust], in "Steaua”, 8.

Blaga, L. (1957b). In loc de prefață [Instead of a Preface], in Din lirica universală. Tălmăciri de Lucian Blaga [Poetry from World Literature. Translations by Lucian Blaga], State Publishing House for Literature and Art, Bucharest.

Blaga, L. (1972). Faust și problema traducerilor [Faust and the Issue of Translations], in Isvoade: eseuri, conferințe și articole

[Notes: Essays, Conferences and Papers], volume coordinated by Dorli Blaga and Petre Nicolau, preface by George Gană, Minerva, Bucharest.

Blaga, L. (1977). Elanul insulei [The Upsurge of the Island], Dacia, Cluj-Napoca.

Blaga, L. (2010). Opera poetică [Poetry], Humanitas, Bucharest.

Cenușă, M. (1989). Lucian Blaga. Corespondență [Lucian Blaga. Correspondence], Dacia, Cluj-Napoca.

\footnotetext{
21 "As a result of our own examination, we must note that Romanian translation studies, as part of Central European translation studies, are less based on linguistic and translation reflections articulated within the national area, and more centered on foreign, Western translation theories" (Lungu-Badea, 2017, p. 16).
} 
Cercel, L. (2017). Sean Cotter, Literary Translation and the Idea of a Minor Romania - a review, in "Finnish Journal for Romanian Studies", 3, p. 75-80.

Cotter, S. (2008). The Soviet Translation: Romanian Literary Translators after World War Two, in "Meta: Journal des traducteurs", 53 (4), p. 841-859, Crossref.

Cotter, S. (2014). Literary Translation and the Idea of a Minor Romania, University of Rochester Press, Rochester.

Iordan, I. (1949). Influențe rusești asupra limbii române [Russian Influences on Romanian Language], in "Annals of the Academy of the Popular Republic of Romania", Publishing House of the Popular Republic of Romania, Bucharest.

Jeanrenaud, M. (2015). Some reflections on Romanian translation studies, in "Diacronia", 2, July 17, art. A20, Crossref.

Lenz, H. (2017). Despre o traducere în franceză a Jurnalului de călătorie în China al lui Nicolae Milescu (Spătarul) [On a French translation of the China Travel Diary by Nicolae Milescu (Spătarul)], in Lungu-Badea, G. \& Obrocea, N. (coord.), Studii de traductologie românească, I. Discurs traductiv, discurs metatraductiv [Romanian Translation Studies. I. Translation Discourse and Meta-discourse], Publishing House of the West University, Timișoara, p. 115-133.

Lungu-Badea, G. (2017). Translation Studies in Romania. Their synchronic and deferred relations with European translation studies. A few directions of research, in Schippel, L. \& Zwischenberger, C. (eds), Going East: Discovering New and Alternative Traditions in Translation Studies, Berlin, Frank \& Timme.

Montesquieu (1956). Lettres persanes, Garnier, Paris.

Peeters, J. (1999). La médiation de l'étranger. Une sociologie de la traduction, Artois Presses Université, “Traductologie”, Arras.

Poncet, J. (1996). Oser traduire Blaga, în Les marches insoupçonnées, volume comprising the papers presented during international conferences dedicated to Lucian Blaga held by the Romanian Cultural Centre in Paris (May 1995-May 1996), supplement to "Cahiers Bleus", collection "Les colloques internationaux Lucian Blaga”, Troyes.

Ricœur, P. (2004). Sur la traduction, Bayard, Paris.

Sapiro, G. (2012). Editorial policy and translation, în Handbook of Translation Studies, volume edited by de Gambier \& van Doorslaer, $3^{\text {rd }}$ volume, John Benjamins, Amsterdam, Crossref.

Schippel, L. \& Zwischenberger, C. (2017). Going East: Discovering New and Alternative Traditions in Translation Studies, Berlin, Frank \& Timme.

Vatamaniuc, D. (1977). Lucian Blaga. Bibliografie [Lucian Blaga. Bibliography], Scientific and Encyclopaedic Publishing House, Bucharest.

Venuti, L. (1995). The Translator's Invisibility: a History of Translation, Routlege, London/New York, Crossref.

Vianu, T. (1956). Literatură universală și literatură națională [World and National Literature], State Publishing House for Literature and Art, Bucharest.

Vischer, M. (2009). La traduction, du style vers la poétique : Philippe Jaccottet et Fabio Pusterla en dialogue, Éditions Kimé, Paris. 